\title{
A VIRTUALIDADE DO SENTIDO EM MACHADO DE ASSIS
}

Marcílio França Castro Universidade Federal de Minas Gerais

\section{Entre um século e outro}

\section{A mirada virtual}

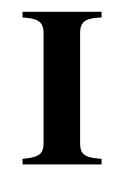

magens como a de um gato que se mantém vivo e morto ao mesmo tempo dentro de uma caixa fechada ou a de um corpo que está em vários lugares simultaneamente deixaram de ser, neste final de século, mera inspiração fantástica da mente humana para se tornarem referência em sérias pesquisas de investigação científica.

Experiências realizadas em 1910 pelo cientista alemão Werner Heisenberg, com partículas no interior de átomos, vieram sugerir a possibilidade de que situações envolvendo a fusão múltipla de tempos e espaços pudessem verdadeiramente acontecer. A teoria de Heisenberg, que ficou conhecida pelo nome de princípio da incerteza, limitava-se, na verdade, à descrição de fenômenos do chamado universo subatômico e baseava-se na evidência de que era impossível determinar com precisão, num mesmo momento de verificação, a velocidade e a posição de uma partícula em movimento, como, por exemplo, um elétron.

A ciência hoje - e o pensamento ocidental de um modo geral - parece ter avançado em direção à concretização dessas estranhas possibilidades. Numa experiência realizada nos Estados Unidos em 
abril de 1996, dois cientistas daquele país ${ }^{1}$ conseguiram fazer com que um átomo de berilo, magneticamente isolado, respondesse igualmente aos estímulos lançados para detectar a sua presença em dois espaços distintos num mesmo instante de tempo.

A visão de uma criatura que se pressente mas não se pode identificar, como o elétron que se desloca fantasmagoricamente ou o átomo que se duplica sendo um só, certamente é muito útil para ilustrar o modo difuso como o homem contemporâneo vem interpretando o mundo. A percepção científica funciona, aqui, como uma metáfora do olhar com que se constrói o final do século nas diversas áreas do conhecimento e da arte, como a política, a filosofia e a literatura.

Essa perspectiva da virtualidade e da indeterminação que se projeta em vários campos das relações humanas, quebrando a solidez de muitas referências materiais e simbólicas, abre caminho, na literatura, para que se estabeleçam, com textos de outras épocas, às vezes já tão lidos e cansados, conexões ainda não de todo reveladas. É o que pode sugerir, hoje, a leitura de algumas narrativas de Machado de Assis, como os contos O Alienista e Missa do Galo. Cem anos depois, ou cem anos agora, talvez seja possível, no diálogo da escrita com o tempo, a redescoberta de uma estranha miragem que os une e atravessa.

\section{A lógica machadiana}

Uma das características mais significativas da narrativa machadiana, porque definiu a sua ruptura com a tradição da especularidade e da linearidade que dominava a ficção do século XIX, é a da relativização dos fatos e conceitos por meio da flexibilização da linguagem. O discurso machadiano, ao quebrar a idéia de relação bi-unívoca entre a realidade e representação, faz ruir a noção de um real fixo, unidimensional e objetivo e promove a

\footnotetext{
${ }^{1}$ Trata-se de David Wineland e Chris Monroe, do Instituto Nacional de Padrões e Tecnologia (NIST), situado em Boulder, nos EUA.
} 
inserção do leitor no jogo de construção (ou perseguição) do sentido. $^{2}$

Se, nas narrativas do século XX, a reação contra a fixidez da representação ocorre, em grande parte, pela fragmentação discursiva e pela subversão da sintaxe, num processo que, acentuado na ficção contemporânea, Fredric Jameson pertinentemente relacionou com a expressão de sintomas da esquizofrenia, ${ }^{3}$ em Machado de Assis a ruptura com a expressão clássica se dá em outro nível. Penetra-se no campo subliminar da linguagem, em que não se produz necessariamente a quebra da linearidade sintagmática das frases e dos períodos. A relatividade como eixo do pensamento é construída na divergência e no paradoxo surgidos nos diálogos interiores do texto. Mantémse em geral a linha da cadeia significante e o lastro de textualidade; sob essa superfície pelicular, porém, escorrega o sentido. ${ }^{4}$

A mobilidade digressiva da narrativa machadiana impõe à sua ficção uma condição de pluralidade que significa não apenas contar várias histórias ao mesmo tempo, dentro do espírito da literatura moderna, ao qual se referiu Gilles Deleuze, ${ }^{5}$ mas também, e principalmente, virtualizar, em uma só, várias histórias ao mesmo tempo.

${ }^{2}$ Cf. BRAYNER, 1979, p. 87: "Machado de Assis inaugurou os elementos e formas para sublinhar um moderno conceito de romance, fruto de visão flexível da linguagem."

3 JAMESON, 1996, p.53 e seguintes.

${ }^{4}$ A idéia da relatividade é várias vezes abordada ironicamente por Machado, como nesta fala do narrador em Memórias Póstumas de Brás Cubas: "Era fixa a minha idéia, fixa como... Não me ocorre nada que seja assaz fixo neste mundo: talvez as pirâmides do Egito, talvez a finada dieta germânica.”. E o próprio Machado, em um texto de crítica literária, revelou seu pensamento sobre a natureza multiprismática da arte: "Se a exata cópia das coisas fosse o fim da arte, o melhor romance seria a reprodução taquigráfica de um processo judicial".

${ }^{5}$ Cf. DELEUZE, 1994, p.266: "Não se trata de forma nenhuma de pontos de vista diferentes sobre uma história que se supõe ser a mesma (....). Trata-se, ao contrário, de histórias diferentes e divergentes, como se uma paisagem absolutamente distinta correspondesse a cada ponto de vista." 
É assim que muitos dos textos machadianos se inscrevem numa dimensão de instabilidade que, ao lançar o leitor por uma galeria de hipóteses sobre fatos e comportamentos narrados, impede que ele consiga precisar o que realmente aconteceu ou existiu. Pode-se dizer, assim, que várias das narrativas criadas por Machado remetem para uma dimensão de virtualidade e incerteza curiosamente semelhante à que permeia as relações contemporâneas.

\section{O Alienista: ensaio para um narrador quântico}

\section{A angústia do sentido}

A apropriação, pelo narrador machadiano, de certos discursos que usualmente se vinculam a grupos, classes ou pessoas política, religiosa ou sócio-culturalmente caracterizados, tem como resultado a desconcatenação dos valores que eles carregam e a problematização da lógica estigmatizante do pensamento.

Em O Alienista, é no campo de contradições entre razão e loucura e entre ciência, moral e política que se tecerá a trama volátil da narrativa, por meio da ação sedutora do narrador. O conto trata dos episódios que, "em tempos remotos", se sucederam na pequena cidade de Itaguaí após a chegada de Simão Bacamarte, "ilustre" cientista que se propunha a "agasalhar e tratar no edifício que ia construir todos os loucos de Itaguaí e das demais vilas e cidades".

O narrador, ao contar a tortuosa história dos fatos envolvendo Simão Bacamarte e a população local - as curiosas operações de internação e liberação de doentes mentais na chamada Casa Verde e os conflitos morais e políticos deflagrados por essa movimentação - oscila de modo sutil entre a crítica e o elogio da ciência, entre o deboche e o aplauso ao alienista, entre a crença na realidade dos acontecimentos e a suspeita de sua ilusão. O narrador, assim como a história, mantém-se sempre no limite permanente da dúvida.

Se acompanhamos com cuidado o percurso irônico do narrador e observamos a sua atitude quanto a Simão Bacamarte, 
quanto à sociedade itaguaiense e quanto ao próprio leitor, veremos como uma suposta coerência de comportamento, inicialmente admitida, se desmancha ao longo da narrativa.

A postura do narrador com relação à figura de Bacamarte parece ser, nos primeiros momentos da história, a de uma ironia bem definida, que se manifesta por meio de pistas evidentes no texto, como, por exemplo, a estranha naturalidade com que se apresentam os fantásticos atributos do cientista - "o maior dos médicos do Brasil, de Portugal e das Espanhas" - e o cinismo com que se descrevem a sua "impressionante" sabedoria e a obsessão pelo procedimento científico. A investigação mais detida sobre o texto, no entanto, virá obrigar a uma revisão dessa impressão preliminar.

Para ganhar a confiança do leitor, o narrador estrategicamente constrói uma relação de cumplicidade entre os dois, metendo-se, a si e ao outro, na contemplação da cena narrada, em um ponto de observação que ele forçosamente insinua seja comum a ambos. Vejase a seguinte passagem, na voz do narrador:

Mas a ciência tem o inefável dom de curar todas as mágoas; o nosso médico mergulhou inteiramente no estudo e na prática da medicina. Foi então que um dos recantos desta lhe chamou especialmente a atenção, - o recanto psíquico, o exame da patologia cerebral. (p. 18)

Essa estratégia de inclusão do leitor, comum em Machado de Assis, funciona como uma tentativa de iludi-lo no que diz respeito à veracidade do discurso do narrador. Assim, é possível manipular os acontecimentos e conformá-los de tal modo que o leitor seja levado a participar, na artificial condição de co-autor, das ironias básicas articuladas no plano da narração, como ocorre, por exemplo, na passagem abaixo, em que a percepção relativa ao absurdocômico do comportamento de Bacamarte fica tacitamente compartilhada entre narrador e leitor:

\footnotetext{
${ }^{6}$ MACHADO DE ASSIS, 1990. Todas as citações do conto O Alienista utilizadas neste ensaio são retiradas da mesma edição, e as páginas são as indicadas entre parênteses.
} 
Como fosse grande arabista (Simão Bacamarte), achou no Corão que Maomé declara veneráveis os doudos, pela consideração de que Alá lhes tira o juízo para que não pequem. A idéia pareceu-lhe bonita e profunda, e ele a fez gravar no frontispício da casa; (....) (p. 20)

(....) na verdade, a paciência do alienista era ainda mais extraordinária do que todas as manias hospedadas na Casa Verde; nada menos que assombrosa. (p.23)

Tomando os exemplos acima, seria bastante razoável pensar no narrador como um crítico da ciência, ou de sua pretensa objetividade, ou ainda como uma voz que inteligentemente duvida dos limites entre sanidade e razão. Uma visão constelar da narrativa irá mostrar, porém, que não é exatamente apenas isso o que ocorre.

No momento em que o narrador começa a descrever os vários tipos de perturbação mental que acometem os internados na Casa Verde, vai tornando-se claro o rompimento com a perspectiva irônica alinhavada no começo, e que tomava como alvo principal Simão Bacamarte - ou tudo o que suas idéias pudessem alegoricamente representar.

Nesse processo de disjunção da narrativa, o discurso do narrador passa a se apropriar, ou se mascarar, como se verá mais adiante, do discurso do próprio alienista, ou de fórmulas que haviam sido, até então, atribuídas, direta ou indiretamente, à sua lógica satirizada - de pensamento. A obsessão em classificar e sistematizar, por exemplo, faz parte do caráter de Simão Bacamarte e constitui traço fundamental, no âmbito do mapeamento semântico da história, do que se poderia chamar de discurso da ciência. O narrador, que o vinha depreciando, passa deliberada e sutilmente a incorporá-lo, a fim de ferir outro alvo: as personagens simplórias da loucura cotidiana.

A interseção tênue entre o discurso do narrador e o discurso da ciência, para ridicularizar o comportamento humano descrito nos tipos de Itaguaí, promove uma fissura irreversível na seqüência irônica. Multiplicam-se os alvos da ironia, multiplicam-se as formas de discurso, cria-se um paradoxo, o sentido explode em infinitas direções. 
Cabe aqui um breve esclarecimento teórico. Um texto que conta uma história em vários níveis de significação é um texto que, naturalmente, potencializa as perspectivas de leitura. Um texto complexo, que conta várias histórias entrelaçadas umas com as outras, em vários âmbitos de significação, também é um texto que se pode atualizar ou interpretar de várias maneiras. Um texto, por sua vez, que, independentemente dos planos de significação, cria paradoxos insuperáveis é um texto que joga no território enigmático do sentido.

A significação opera na ordem da lógica comum, da representação cartesiana, e remete a conceitos de alcance geral, estabelecidos no âmbito do pacto social da linguagem. ${ }^{7}$ Leituras críticas fundadas em critérios psicologizantes, filosóficos ou historicizantes, como resumiu Juracy A. Saraiva, ${ }^{8}$ foram possíveis em Machado de Assis graças à complexidade do seu tecido ficcional. Essas leituras consistiram em atualizações diversas da obra machadiana; souberam atribuir-lhe, cada qual a seu modo, um significado social, cultural, político, dentro da lógica da significação.

O sentido, porém, surge como o espaço de fuga da significação ou o lugar em que os paradoxos desta se manifestam; o sentido está onde a significação falha. ${ }^{9}$ Está no âmbito do incorpóreo, daquilo que a razão busca mas não consegue alcançar. O sentido é o insistente objeto de perseguição, que tende para a intangibilidade.

Ao contrário da estabilidade que supõe a significação, porque esta se liga à convenção, o sentido não se contém nos limites segmentados da língua; recusa-os e predispõe o leitor a persegui-lo.

${ }^{7}$ DELEUZE, 1994, p.23. A afirmação é fundamental: "É curioso constatar que toda obra lógica diz respeito diretamente à significação, às implicações e conclusões, e não se refere ao sentido a não ser indiretamente - precisamente por intermédio dos paradoxos que a significação não resolve ou até mesmo ela cria."

${ }^{8}$ SARAIVA, 1993, p.1-6.

${ }^{9}$ DELEUZE, 1994, p.253. 
Por isso nunca se fixa. Se a significação pode ser recortada no tempo, no espaço ou em campos de representação, o sentido tem um caráter eminentemente evasivo. O sentido é a significação que se descolou da proposição e não se pôde mais acorrentar. A significação se decifra, o sentido se pressente. Num raciocínio extremo, poder-se-ia dizer que a busca do sentido é a busca de compreensão da própria existência. E esta perquirição está irremediavelmente presente na narrativa dO Alienista, e em grande parte da obra machadiana.

\section{As formas da ironia}

Os fragmentos a seguir mostram como o narrador dO Alienista - encarnando e desencarnando Simão Bacamarte ao mesmo tempo - serve-se das "teorias" deste para debochar da bestialidade humana, sem, porém, aliar-se completamente ao seu discurso, que continua vazado em um certo ridículo e estupidez:

A mania de grandeza tinha exemplares notáveis. O mais notável era um pobre-diabo, filho de um algibebe, que narrava às paredes (porque não olhava nunca para nenhuma pessoa) toda a sua genealogia, que era esta:

- Deus engendrou um ovo, o ovo engendrou a espada, a espada engendrou o duque, o duque engendrou o marquês, o marquês engendrou o conde, que sou eu. (p. 22)

Outro da mesma espécie era um escrivão, que se vendia por mordomo do rei; outro era um boiadeiro de Minas, cuja mania era distribuir boiadas a toda a gente, dava trezentas cabeças a um, seiscentas a outro, mil e duzentas a outro, e não acabava mais. Não falo dos casos de monomania religiosa (....). (p.22)

Era um rapaz de trinta anos, amável, conversado, polido, tão polido que não cumprimentava alguém sem levar o chapéu ao chão; na rua, acontecia-lhe correr uma distância de dez a vinte braças para ir apertar a mão a um homem grave, a uma senhora, às vezes a um menino, como acontecera ao filho do juiz de fora. Tinha a vocação das cortesias. (p.38) 
Vê-se que o narrador, nas circunstâncias acima, assume, pelo menos em parte, a perspectiva de Simão Bacamarte (o discurso da ciência), a mesma que, paradoxalmente, constituía, como já vimos, o objeto aparente da articulação irônica. O discurso do narrador e o discurso da ciência convergem na medida em que exploram, ambos, as excentricidades do comportamento humano, o circo de manias que é a sociedade.

Surge daí um discurso ao mesmo tempo irônico e ironizado. Se, antes, supunha-se a ironia à ciência, depois, supõe-se a ironia à loucura, mas um tanto através do discurso da ciência. Isso sem abandonar-se a própria ironia à ciência, que também permanece formando um leque aberto de sentidos numa rede virtual.

Instala-se deste modo o jogo da indeterminação levada ao infinito, ou ao absurdo. ${ }^{10}$ Tem-se um processo de relativização, que propicia a eclosão de sentidos múltiplos e simultâneos para a narrativa, formando o que se poderia chamar de um complexo virtual. Dentro desse complexo, o que importa não é saber se o narrador ou o autor é contra ou a favor, ou se o fato ocorreu ou não ocorreu, mas sim entender que todas as possibilidades existem ao mesmo tempo, incertamente, num universo que lembra o das partículas quânticas das experiências de Heisenberg.

A ruptura de um possível encadeamento linear - e estável de ironias, pela mudança sutil no comportamento do narrador, impõe a retomada imediata da leitura das passagens iniciais do conto. Toda afirmativa, que antes se podia aceitar como parte de uma linha lógica, que aparentemente contornava um plano de

\footnotetext{
${ }^{10}$ Wayne C. Booth, comentando Kierkgaard, afirma que o filósofo deveria ter definido a ironia como "absoluta negatividade infinita", isso porque "a ironia em si mesma abre dúvidas assim que sua possibilidade entra em nossas cabeças, e não há nenhuma razão inerente para descontinuar o processo de dúvida em nenhum ponto próximo do infinito.(....); procurada até o fim, uma condição irônica pode dissolver tudo numa cadeia infinita de solventes.". BOOTH, 1994, p.11-42.
} 
significação, é imediatamente posta sob suspeita, e mesmo nas ironias mais óbvias, em que parecia evidente a remissão a um determinado ponto de vista, não se pode concluir que o narrador está usando apenas uma máscara.

A ironia n'O Alienista está, pois, sempre relacionada com a forma heterogênea pela qual o discurso do narrador se apresenta; a ironia está, em síntese, na indeterminação do sentido do discurso do narrador, indeterminação esta que tende a ampliar-se para a narrativa como um todo, contaminando todo o espaço da interpretação.

Trata-se aqui da chamada ironia em segundo grau, ou também denominada ironia filosófica ou humor. Ela não tem como objetivo simplesmente fazer a brincadeira ou o jogo de insinuar, implicitamente, o contrário do que foi dito textualmente; esta manobra caracteriza uma ironia rudimentar, definida como ironia retórica ou ironia estável, ${ }^{11}$ que se anuncia no âmbito dos jogos de significado. Calcada na experiência da relatividade, a ironia de segundo grau desmistifica a ironia retórica e remete à ilusão da palavra, à sua indeterminação, à percepção de que, pela própria natureza da linguagem, é impossível fixar um sentido único para as coisas. ${ }^{12}$

${ }^{11}$ BOOTH, 1994, p.13.

${ }^{12}$ Lélia Parreira Duarte resumiu as características básicas da ironia de segundo grau ou humor: "(....)seu objetivo não é identificar discurso e verdade mas é, ao contrário, a demonstração do caráter reversível da palavra, vista como significante vazio ao qual podem ser atribuídos $\mathbf{n}$ significados. Enquanto o campo da ironia retórica é o do engano, da sedução, o da ironia literária é o da denúncia dos jogos de enganos, da desmistificação da sedução, do bordado em torno do vazio, no lugar onde a linguagem se confessa construção, artifício, busca ilusória de significação.”. DUARTE, 1991. p.7-10. 


\section{Entre o verdadeiro, o falso e o vazio}

Em Machado de Assis, não há, de um modo geral, como confiar no comportamento e nas opiniões do narrador. Não se consegue precisar com segurança que idéias ele efetivamente defende ou os fatos que está relatando. Figura dúbia e contraditória, multiplicada em vozes alternadas e imprevisíveis, o narrador do Alienista (assim como o de Memórias Póstumas de Brás Cubas), ou o da Missa do Galo, de que se tratará mais adiante, não se comporta como um sujeito de pensamento lógico e argumento linear; sugere ser, antes, um espectro verbal que encarna evasivamente expressões e juízos diversos e paradoxais.

As mudanças no discurso do narrador-ironista e na expressão de seus pontos de vista revelam a sua natureza de simulacrofantasma, corpo poroso e movediço que aboliu a figuração do principal e do secundário, do falso e do verdadeiro, da realidade e da ficção. ${ }^{13} \mathrm{O}$ narrador, ao refratar-se como um duplo de si mesmo, ao vagar como uma sombra à volta de Simão Bacamarte, ao interporse entre o olhar da fé e o da ciência, dando as mãos às duas e traindo a ambas, ao evocar o registro fiel dos "cronistas" de Itaguaí - para dar credibilidade aos fatos - e, ao, contraditoriamente, aceitar a hipótese de que tudo poderia não passar de um mero boato, em todas essas situações, apresenta-se como um simulacro de si mesmo, uma ciranda de máscaras umas sobre as outras, em todas as direções, sem centro, sem raiz, na superfície. O narrador é o desvio ou a perversão de si próprio, um mesmo que é também o outro, num estado dinâmico de auto-dessemelhança:

Sobre o lábio fino e discreto do alienista roçou a vaga sombra de uma intenção de riso, em que o desdém vinha casado à comiseração; mas nenhuma palavra saiu de suas egrégias entranhas. A ciência contentou-

${ }^{13}$ DELEUZE, 1988, p.263: "O simulacro inclui em si o ponto de vista diferencial; o observador faz parte do próprio simulacro, que se transforma e se deforma com seu ponto de vista.". 
se em estender a mão à teologia, - com tal segurança, que a teologia não soube enfim se devia crer em si ou na outra. (p.29)

Não se pode falar, no que se refere ao narrador, e nem no que se refere a Simão Bacamarte, ou a D. Evarista, ou a Crispim Soares, em um original ou em uma cópia, no comportamento de algum deles que seja antes o verdadeiro ou o dissimulado. Não há uma personalidade primeira a ser considerada, em detrimento de outras, secundárias. Há um jogo de imagens-comportamento na dimensão do simulacro. Não há exatamente transgressão, há alternância. Assim, a seqüência interrompida de ironias que usamos para demonstrar o deslocamento evasivo da perspectiva do narrador deve ser tomada apenas como artifício de raciocínio, não havendo qualquer aspecto da figura do narrador que, por ter aparecido antes ou depois na narrativa, prevaleça sobre outro: todas as versões participam simultaneamente da virtualidade do sentido. Anarquia contra hierarquia.

Curiosamente, a atitude vacilante do narrador - instituída na fronteira entre enunciação e enunciado - remete, como que num campo de tensões polares em níveis diversos, às vicissitudes no comportamento de alguns personagens-chave da narrativa, e para cuja inconstância e pusilanimidade o narrador não confere perdão. Refiro-me às personagens do barbeiro Porfírio e de Crispim Soares: o primeiro, de opositor de Simão e líder da multidão contra o arbítrio do médico, passa a seu simpatizante e comparsa; o segundo, de cúmplice de Simão, passa a seu traidor, num jogo hilariante de fraquezas e conveniências. Este movimento das personagens pode ser avaliado como um complicador na questão da loucura e da sanidade, fazendo sombra ao dilema entre o narrador e Simão.

Repare-se ainda que Simão Bacamarte, diferentemente do narrador e da maior parte das personagens, consegue manter, dentro de um raciocínio obstinado e extremista - campo aberto para a loucura -, um comportamento rigorosamente coerente com os preceitos que ele defende: o método científico levado às suas últimas conseqüências, o que redundou, ao final, na sua reclusão solitária na Casa Verde. 
Em relação a Simão Bacamarte, ao povo de Itaguaí, a toda a aventura entre doidos e lúcidos da cidade, fica a seguinte indagação, que é a mesma explorada por Gilles Deleuze: Em que sentido as coisas acontecem? A narrativa armou um paradoxo sem solução. ${ }^{14}$ As respostas desintegram-se como líquido oleoso na superfície plana e agora há um fantasma que repete a pergunta: em que sentido?

Podemos atribuir um significado histórico, outro filosófico, outro sociológico, ao que se passa em Itaguaí, e todos eles se referem a instâncias interpretativas da significação. Nesse plano, a personagem, o fato ou a história - espaços virtuais da literatura -, em estado de suspensão, se presentificam mediante o processo interpretativo da leitura, a que Gilles Deleuze chamou de atualização. ${ }^{15} \mathrm{Nela}$, o leitor dimensiona os aspectos, fragmentos e conjuntos de significação virtualmente existentes no texto, interseccionando-os com o espaço múltiplo de sua memória. Entretanto, o território do sentido, que rejeita condensações ou sistematizações lógicas, também está mo âmbito do virtual. E, no conto de Machado, a virtualidade do sentido atravessa os campos de significação, incursionando por eles, subvertendo-os, quase destruindo-os.

Permanece a pergunta: em que sentido as coisas acontecem? Hoje, no cenário das sociedades tecnologicamente complexas, parece ser mais fácil aceitar essa convivência antípoda de realidades, que Machado conscientemente talvez não tivesse notado.

${ }^{14}$ DELEUZE, 1994, p. 9.

${ }^{15}$ Para o pensador francês, o virtual constitui uma parte completa e incorpórea de um objeto, uma porção da existência real que reúne os elementos e as relações da estrutura total do objeto, mas que não o é em sua inteireza. Vejase: "A natureza do virtual é tal que atualizar-se é diferenciar-se para ele. Cada diferenciação é uma integração local, uma solução local, que se compõe com outras no conjunto da solução ou na integração global. (....). Atualizarse, para um potencial ou um virtual, é sempre criar linhas divergentes que correspondam, sem semelhança, à multiplicidade virtual. $\mathrm{O}$ virtual tem a tarefa de uma realidade a ser cumprida, assim como a realidade de um problema a ser resolvido." DELEUZE, 1988, p. 339 e 341. 
Retirada a máscara do narrador, e visto que não tem fundo, podemos nos deliciar com a inconsistência provocante de suas observações:

Crispim Soares, ao tornar a casa, trazia os olhos entre as duas orelhas da besta ruana em que vinha montado; Simão Bacamarte alongava os seus pelo horizonte adiante, deixando ao cavalo a responsabilidade do regresso. Imagem vivaz do gênio e do vulgo! Um fita o presente, com todas as suas lágrimas e saudades, outro devassa o futuro com todas as suas auroras. (p. 26)

O alienista sorriu, mas o sorriso desse grande homem não era cousa visível aos olhos da multidão; era uma contração leve de dous ou três músculos, nada mais. (p. 43)

O grande homem de que nos fala o narrador conseguer ser, a um só tempo, genial e desprezível, preciso e delirante, numa variação de caráter que a expressão movediça da narrativa não permite decifrar. O grande homem é, também, mísero; é louco e é são, como um fantasma de mil faces, uma alegoria de opostos. A sua presença em Itaguaí e o efeito de sua intervenção na comunidade não passarão jamais, como conclui o narrador, de um boato duvidoso, uma conjectura, como de fato podemos crer que seja a aventura do ser humano pela Terra:

Alguns chegam ao ponto de conjecturar que nunca houve outro louco, além dele, em Itaguaí; mas esta opinião, fundada em um boato que correu desde que o alienista expirou, não tem outra prova, senão o boato; e boato duvidoso, pois é atribuído ao padre Lopes, que com tanto fogo realçara as qualidades do grande homem. Seja como for, efetuouse o enterro com muita pompa e rara solenidade. (p. 66)

Se, em O Alienista, procuramos um narrador que faz a crítica da ciência, nós o encontramos. Se procuramos um narrador que adere às fabulações megalomaníacas de Simão Bacamarte, também o encontramos. Se procuramos um narrador que debocha da população e de Simão Bacamarte, há sinais para localizá-lo. Ele responde a todas as convocações; está em todas as posições e não está em nenhuma delas. Escorrega, infiltra-se, trapaceia. E como, 
depois de supostamente identificá-lo, ter a certeza de que, sem máscara, por seu próprio juízo, não estará ele, exatamente ao contrário, fingindo a convicção que supusemos que ele tinha?

Não é à toa que a idéia da dissimulação e do mascaramento aparece tão desenvolvida nos romances e contos de Machado, tanto nos da chamada fase romântica, em que o narrador não liberara todo seu requinte de sarcasmo, deboche e ironia, quanto nos conhecidos como sendo da fase realista. ${ }^{16}$ Em qualquer dos casos, a estética da farsa é o jogo da escrita, cuja solução não consiste em decifrar o verdadeiro pensamento das personagens ou do narrador, mas sim em perceber o mascaramento do próprio jogo.

Vem dessa incerteza a justificativa para qualificar atualizadamente o narrador em Machado de Assis como um narrador quântico-ou, mais precisamente, como uma versão precursora dele - e usufruir de todas as imagens que esse atributo pode oferecer na leitura contemporânea de seus textos. Sujeito que se move como partícula, incapturável, infixável, deslocando-se imprevisivelmente diante do olhar também imprevisível de seu espectador.

${ }^{16}$ Vejam-se alguns exemplos da estética do mascaramento, sugerida obsessivamente pelo narrador no comportamento de algumas personagens de Iaiá Garcia - "Procópio Dias fez primeiro um gesto afirmativo; depois balbuciou a confissão plena de seus sentimentos, mas com um ar envergonhado, meio sincero e meio fingido, e tão a ponto e natural, que era dificil saber onde acabava a sinceridade e onde começava a simulação." "Algumas pessoas foram despedir-se dele (Jorge), e acompanhar a mãe no solene momento de despedida. Entre essas figurava o pai de Estela, cuja tristeza, que era sincera, trazia uma máscara ainda mais triste." Ou: "Iaiá tinha aplacado a primeira sensação: afivelou de todo a máscara da tranqüilidade, enquanto não a substituía por outra."

17 MACHADO DE ASSIS, 1990. Todas as citações do conto Missa do Galo usadas neste estudo foram retiradas da mesma edição. As páginas são as indicadas entre parênteses. 


\section{Missa do Galo: a letargia do sentido}

Concordei, para dizer alguma cousa, para sair da espécie de sono magnético, ou o que quer que era que me tolbia a lingua e os sentidos. (p. 23) ${ }^{17}$

Assim como a manipulação irônica do discurso pelo narrador produz, em O Alienista, a rarefação do sentido e a sua remissão ao domínio de uma virtualidade complexa, em Missa do Galo, a exemplo do que ocorre não raramente em outros textos de Machado, é possível observar a marca de um artifício discursivo que, sincronicamente articulado com a ironia, estabelece um campo de enigmas virtuais. Trata-se da ambigüidade, articulada nos vários níveis da narrativa: significação embaçada e sentido aberto, o conto mergulha em uma atmosfera de dúvida fantástica que nunca se resolve:

Nunca pude entender a conversação que tive com uma senhora, há muitos anos, contava eu dezessete, ela trinta. (p.57).

Esta é a fórmula que inaugura o universo de dubiedades do conto: a conversação cujo sentido jamais se esclareceu, passada num tempo distante, entre um jovem adolescente, de dezessete anos, e uma mulher casada, com trinta.

Qual seria o interesse da história, que não se sabe direito o que foi, nem exatamente como ocorreu? É o caráter emblemático do parágrafo introdutório, sustentado ao longo da narração, que constitui a própria razão de ser do conto.

A ambigüidade na Missa do Galo pode ser compreendida, em seus diversos aspectos, pela visualização de um conjunto de traços discursivos reunidos em uma espécie de campo letárgico, que se arma no domínio da narrativa. Perceber os elementos que o constituem pode ser extremamente útil para a admissão de uma possível ótica da virtualidade e do paradoxo.

O território letárgico pode ser aqui concebido como um campo de tensão entre situações contraditórias ou excludentes, 
convivendo em um estado de ambigüidade permanente. $\mathrm{Na}$ narrativa, alguns índices o prefiguram: a oposição contínua entre imaginação e realidade; os estados de transição (sonolência, delírio, musicalidade, loucura, sedução, erotismo); a temporalidade remota; o discurso amnésico; o discurso da vacilação; o discurso da medianidade.

A ambigüidade está bastante próxima da ironia, na medida em que remete à multiplicidade de significados para a proposição e aponta para uma espécie de síndrome do sentido. A distinção que aqui nos interessa considerar entre as duas espécies, para efeito de análise de textos machadianos, é a seguinte: a ironia é produzida na alternância e na ocultação de fatos e opiniões. É o discurso da dissimulação. A ambigüidade, por sua vez, consiste na expressão de duplicidade, na atmosfera de dúvida sobre a situação ficcional, que o narrador não tenta ocultar. É o discurso da bifurcação.

A Missa do Galo se desenvolve num ambiente de sonolência contínua e envolvente. O trânsito vagaroso entre dormire acordar fabrica a hipnose que delimita o território letárgico e mantém a tensão entre imaginação e realidade:

Dentro em pouco estava completamente ébrio de Dumas. (...) Entretanto, um pequeno rumor que ouvi dentro veio acordar-me da leitura. (p. 58)

Duas ou três vezes, pareceu-me que a via dormir; mas os olhos, cerrados por um instante, abriam-se logo sem sono nem fadiga, como se os hovesse fechado para ver melhor. (p.61)

O estado de embriaguez pelo sono é dado não apenas pelo ritmo do diálogo entre Nogueira (nome do narrador-personagem) e Conceição, mas também pelo seu próprio conteúdo:

(...) Depois referiu uma história de sonhos, e afirmou-me que só tivera um pesadelo, em criança. Quis saber se eu os tinha. A conversa reatouse assim lentamente, longamente, sem que eu desse pela hora nem pela missa. (p.61)

Sob a inspiração magnética do sono, insinua-se discretamente o erotismo dos movimentos e das palavras, que faz as personagens 
se aproximarem e envolverem. Constrói-se uma situação-limite, de consciências em suspensão, e amplia-se a virtualidade de cada ato, gesto e frase.

O erotismo sugere a letargia dos corpos num ambiente sem significação. A mínima atitude de Conceição é transportada pelo rapaz para a dimensão do prazer e da transgressão:

Conceição ouvia-me com a cabeça reclinada no espaldar, enfiando os olhos entre as pálpebras meio-cerradas, sem os tirar de mim. De vez em quando passava a língua pelos beiços, para umedecê-los. (p.59)

Não estando abotoadas, as mangas, caíram naturalmente, e eu vi-lhe metade dos braços, muito claros, e menos magros do que se poderiam supor. (p.60)

Note-se que a condição de existência em transe, possível na Missa do Galo pela ação da sonolência e do erotismo, aparece no Alienista principalmene através do conflito gerado pela questão da loucura.

É certo que não há, no Alienista, a configuração de um campo letárgico do modo como acontece na Missa do Galo. A predominância da ironia ou da ambigüidade gera conformações diferentes para os universos ficcionais. Mas, em qualquer dos casos, é inequívoca a tendência das duas narrativas para atingir estados-limite de consciência que evocam o dilema entre representação e vertigem, ou seja, entre significação e sentido.

A distância temporal de um fato que é recuperado nebulosamente pela memória constitui outra marca do território letárgico em Missa do Galo. A identificação longínqua da história, "há muitos anos", numa noite de "1861 ou 1862", não apenas contribui para obscurecer a verdade dos acontecimentos como também afasta o narrador do compromisso com a exatidão. O fato vivido mistura-se, na recuperação seletiva da memória, ao fato sonhado ou imaginado. A cumplicidade do sexo proibido é uma invenção do discurso amnésico:

Há impressões dessa noite, que me parecem truncadas ou confusas. Contradigo-me, atrapalho-me. Uma das que ainda tenho 
frescas é que, em certa ocasião, ela, que era apenas simpática, ficou linda, lindíssima. (p.62)

A ambigüidade cria o paradoxo pela evidência, como a ironia cria o paradoxo pela dissimulação.

Sugerir e negar também faz parte da estratégia de confundir. É isso o que se pode entender como sendo o discurso da vacilação. O narrador várias vezes confunde-se entre, por exemplo, atribuir um impulso provocativo a Conceição e negá-lo em seguida, engasgadamente, livrando-a de qualquer suspeição. Sendo verdadeiramente dele o desejo, ou dela, - o que não importa esclarecer -, as palavras são as dele e projetam uma hipótese acumulada sobre a outra no espaço virtual:

Fitei-a um pouco e duvidei da afirmativa. Os olhos não eram de pessoa que acabasse de dormir; pareciam não ter ainda pegado no sono. Essa observação, porém, que valeria alguma cousa em outro espírito, depressa a botei fora, sem advertir que talvez não dormisse justamente por minha causa, e mentisse para me não afligir ou aborrecer. Já disse que ela era boa, muito boa. (p. 59)

Reforçando a idéia de letargia, que torna possível e mantém a ambigüidade, há um último aspecto que não se pode deixar de mencionar: a cautela constante em descrever a figura e as ações de Conceição, o que a coloca na condição de um ser-fantasma, angelical e demoníaco, quase sempre assustador, numa dinâmica de opostos compatível com a tensão mediúnica do sono. Essa expressão dúbia, vaga e ao mesmo tempo instigante de Conceição está no âmbito do discurso da medianidade:

Em verdade, era um temperamento moderado, sem extremos, nem grandes lágrimas, nem grandes risos. (p.58)

Tudo nela era atenuado e passivo. O próprio rosto era mediano, nem bonito nem feio. Era o que chamamos uma pessoa simpática. Não dizia mal de ninguém, perdoava tudo. Não sabia odiar; pode ser até que não soubesse amar. (p.58) 
A psicanálise certamente ofereceria uma boa explicação para os impulsos de transgressão e repressão do narrador personagem de si mesmo. Interpretações investigatórias dos seus movimentos, milimétrica e cientificamente analisados, talvez também levassem a um veredito definitivo sobre o que de fato se passou naquela noite de Natal. Mas, à parte a ciência e a psicanálise, há algo que está para além da língua e da noção comum de representação, algo ainda quase inexplorado e por isso dificilmente compreendido. A narrativa da Missa do Galo, celebrada em um território letárgico, indica a presença espectral dessa dimensão, em que a fala e o corpo se interrompem para instalar-se outro campo de organização perceptiva: o do sentido. O próprio personagem-narrador, como um elétron imobilizado, aprisiona-se por uma "espécie de sono magnético", que, no tempo-espaço embaçado da memória, presente envolvido com o passado, lhe tolhe "a língua e os sentidos".

Chegamos a ficar por algum tempo, - não posso dizer quanto, inteiramente calados. O rumor único e escasso era um roer de camundongo no gabinete, que me acordou daquela espécie de sonolência; quis falar dele, mas não achei modo. Conceição parecia estar devaneando. (p. 63)

É interessante observar, por fim, como o tecido ambíguo, e também o irônico, constitui campo aberto para o paradoxo. E é igualmente interessante perceber como os estados letárgicos, e também os quânticos, resistem à lógica classificatória da representação. O Nogueira, na Missa do Galo, que vai e vem entre a infância e a maturidade sob as traições da memória, sabe apenas que há um fantasma que o incomoda, um caminho duplo na sua percepção que a racionalidade não consegue sustentar. Para expressá-lo, é necessário incorporar a ambigüidade na sua forma anti-lógica, que admite a existência de universos bifurcados e simultâneos, não hierarquizados, no limite entre a ficção e a realidade. 


\section{O fantasma de Machado no século XXI}

Vive-se hoje uma importante reviravolta nas concepções de espaço e de tempo, promovida em grande medida pela gigantesca expansão dos meios de comunicação, informação e locomoção. A explosão da cultura do audiovisual não apenas tem possibilitado a interligação múltipla e direta entre os homens e lugares mais afastados, como também tem aberto perspectivas de reconstituição de bens e civilizações antes irrecuperáveis.

É notável, em tal condição, a expansão de uma certa dimensão incorpórea da realidade, num movimento que constitui uma verdadeira onda de virtualização. Um dos veículos que melhor exprimem esse processo é a mídia televisiva, que atua como poderosa estação de conexão entre o olhar dos indivíduos e os cenários de realidades fabricadas. Sob o signo do simultaneísmo, que se manifesta na emissão de várias informações distintas ao mesmo tempo, e da fugacidade - os fatos que se esvaem na tela -, o produto-imagem conforma o espaço de uma superfície ilusória e mutante.

Deve-se perceber como a lógica desse universo parece ser mantida, em grande parte, pelo ato de extensão ao infinito do conceito de mercadoria, como fruto da aliança entre capitalismo e tecnologia. Trata-se da possibilidade de transformação de qualquer objeto, fato ou idéia em produto virtual de consumo, numa operação que é mediada pelos meios de comunicação e de publicidade. O resultado dos jogos de linguagem entre a mídia (propaganda e marketing) e o público (opinião e comportamento) passa a ser crucial no desenho dos quadros de poder dentro de qualquer sistema de relações, sejam elas políticas, religiosas, sociais ou culturais.

As decisões e os movimentos políticos, por sua vez, tanto no plano institucional quanto no âmbito de organizações não governamentais, movem-se também, cada vez mais, sob a influência de forças incorpóreas e vacilantes. A articulação se dá, nesse meio, em função das correntes de opinião pública e da publicidade. 
Grupos religiosos, étnicos ou político-partidários, ao tentarem demarcar territórios e absorver poder, vinculam suas ações, muitas vezes sem a mínima coesão ideológica ou comunhão cultural, a imagens e símbolos que, por uma situação de destaque momentâneo, podem render-lhes simpatia e apoio popular. Inúmeros exemplos podem ser anotados sobre a lógica dessas operações, como o trabalho dos organismos internacionais de defesa ecológica ou de mobilização por causas raciais ou culturais. Todos se esforçam por potencializar suas vozes através dos meios de comunicação e têm nas tendências da opinião pública a principal orientação para a escolha - circunstancial - dos seus objetos de reivindicação. ${ }^{18}$

Parece possível dizer, assim, que se vive hoje sob o signo de um tempo vigoroso e, paradoxalmente, fantasmático. Se a sofisticação da imagem e a rapidez da informação aproximam o fato difuso e o tornam um fenômeno sempre imediato, essa mesma

${ }^{18}$ A respeito desse tipo de comportamento, que varia de acordo com a conveniência do instante, é esclarecedora a declaração, dada em 1995, pelo então diretor-executivo do grupo internacional Greenpeace, Thilo Bode. Indagado sobre como o movimento agia para escolher o alvo de uma campanha, ele respondeu: "Primeiro, definimos áreas de atuação, como, por exemplo, proteger a biodiversidade. Depois, escolhemos objetivos mais específicos, como proteção das florestas. Agora vem o importante: se temos cinco possíveis campanhas, escolhemos a que parece estrategicamente mais efetiva, não necessariamente aquela que, cientificamente, seja mais fundamental." (Folha de São Paulo, 17/09/95. p.1-24).

${ }_{19}$ Parece interessante transcrever aqui a observação feita por Robert Kurz a respeito do tempo-espaço capitalista, ao avaliar o pensamento de Virilio sobre a questão: “ (....) ele (Virilio) vincula a concentração do tempo à tecnologia, mas não leva em consideração a forma do tempo-espaço capitalista. Ora, não é a tecnologia em si que dita a necessidade de uma aceleração vazia; pode-se muito bem desligar as máquinas ou fazê-las funcionar mais lentamente. Antes, é o vazio do tempo-espaço capitalista, destacado da vida e sem laços culturais, que impõe à tecnologia uma determinada estrutura e a transforma num mecanismo autônomo da sociedade, impossível de ser desconectado." (Folha de São Paulo. 03/01/99. p.5-3) 
potência dissolve toda a corporeidade dos objetos - a sua condição de duração - num jogo interminável de construir e desmanchar. Figura-se um universo pleno e, ao mesmo tempo, incapturável. ${ }^{19}$

Episódios de grande impacto nas sociedades, como guerras ou catástrofes naturais, tecnologicamente condicionados, misturam-se com casos miúdos da vida privada, de tal modo que o espaço da ficção acaba tornando-se o absurdo da própria realidade. Melhor seria dizer que a realidade, em sua fabricação performática, rouba a cena da ficção e, por isso mesmo, nela se transfigura.

Em face desse cenário, a ficção machadiana, ao explorar a estética do mascaramento e da dissimulação, ao brincar com o vazio da ironia ou com os universos bifurcados da ambigüidade, ao indicar o esgarçamento das fronteiras entre o verdadeiro e o falso, o vivido e o inventado, configura territórios-limite da linguagem que contribuem para a reflexão sobre o discurso que, contemporaneamente, institui a imagem virtual como paradigma existencial.

Ironia e ambigüidade constituem dois meios diferentes e aproximados de criar uma casa de espelhos ou um ambiente de simulacros. E o simulacro é a dimensão por excelência do espaço contemporâneo. Eis aí a convergência fundamental entre a literatura de Machado e o nosso tempo.

O simulacro parece ser mesmo o estado comum entre o sujeito machadiano - narrador e personagens - e a criatura-imagem pósmoderna. O primeiro, dissimulado, se costura nas malhas finas do discurso irônico; o segundo, efeito volátil do capitalismo de informação, configura a própria imagem em mutação, remetendo, muitas vezes, à invenção do clone, ao assexuado, ou simplesmente ao ator performático da política e da propaganda. O sujeito transformista do séc. XXI sugere a caricatura andrógina desvitalizada - do narrador machadiano.

Ambos constituem, porém, um lugar vazio, escasso de significação. Compreendê-los pode significar avançar no espaço do paradoxo, desenvolver uma lógica que domine o campo da incongruência produzida pelo simulacro. Significa criar conceitos 
que vão além daquilo que a aritmética da significação conseguiu explicar, mapear o território hostil do sentido. Não se trata de dominar a contradição e reduzi-la à lógica tradicional; ao contrário, a questão que se põe é transformá-la. Entender o simulacro é entender a virtualidade do sentido.

O sentido não é mais do que a explosão de um relâmpago na montanha, um pressentimento diabólico, uma miragem. A todo instante estamos a atualizá-lo, a confrontar a sua virtualidade fugidia com a inflexão do nosso corpo sobre o seu território. A cada vez que estranhamos o olhar meticuloso de Simão Bacamarte, a cada vez que deformamos o espírito para apreciar a ilusão fantástica da loucura de Itaguaí, estamos atualizando e reinventando, numa percepção que dura quase nada, que é também quase uma ilusão, o sentido que logicamente não conseguimos enxergar.

O gozo sonolento da Missa do Galo, a felicidade plástica que está nos braços de Conceição, no impulso leve e francamente viril do adolescente que amolece e ejacula o seu próprio corpo, são heresias reais e invisíveis de um mundo paradoxal.

Endurecer a vertigem, fotografá-la no momento em surge e já escapole, parecem desafios que afligem como nunca, a necessidade de garantir o sentido da existência num labirinto de imagens. Transformar a gargalhada demoníaca de um jogo de espelhos, o carrossel aterrorizante do mundo a consumir, o pesadelo, numa elaboração frágil, uma brincadeira de brincar. Reconstruir o mito para que ele não nos devore. Rir da loucura e da sanidade após a revolução dos nossos órgãos em contato novo com a tecnologia, a velocidade e o tempo. 


\section{Referências Bibliográficas}

BOOTH, Wayne C. Isto é irônico? Cadernos do NAPq/FALE/UFMG, Belo Horizonte, nำ 17, p.11-42, 1994.

BRAYNER, Sônia. Labirinto do espaço romanesco. Rio de Janeiro: Civilização Brasileira, 1979.

DELEUZE, Gilles. Diferença e Repetição. Rio de Janeiro: Graal, 1988.

DELEUZE, Gilles. Lógica do sentido. São Paulo: Perspectiva, 1994.

DUARTE, Lélia Parreira. Introdução ao Boletim do Centro de Estudos Portugueses da Faculdade de Letras da UFMG. Belo Horizonte, $\mathrm{n}^{\mathrm{O}}$ 13, p. 7-11, jun.1991.

JAMESON, Fredric. Pós-Modernismo. A lógica cultural do capitalismo tardio. São Paulo: Ática, 1996.

LÉVY, Pierre. O que é o virtual? São Paulo: Editora 34, 1996.

MACHADO DE ASSIS, Joaquim Maria. Papéis avulsos (O Alienista). Belo Horizonte/Rio de Janeiro: Garnier, 1990.

MACHADO DE ASSIS, Joaquim Maria. Páginas recolhidas (Missa do Galo). Belo Horizonte/Rio de Janeiro: Garnier, 1990.

SARAIVA. Juracy Assmann. O circuito das memórias em Machado de Assis. São Paulo: Edusp, 1993. 


\section{Resumo}

As noções de tempo e de espaço no fim do milênio transformam-se sob o avanço da tecnologia de comunicação e de informação. Nesse cenário, expandem-se os signos da multiplicidade, da virtualidade e da incerteza. O objetivo do estudo é apresentar uma leitura de Machado de Assis sob a perspectiva da experiência contemporânea, sobretudo para avaliar o discurso do sujeito-narrador nos contos O Alienista e Missa do Galo. Operando com o conceito de virtualidade e com as diferenças entre significação e sentido, procura-se demonstrar como a narrativa, naqueles contos, articulando a ironia e a ambigüidade, quebra a lógica da interpretação e se lança no campo da indeterminação do sentido.

\section{Résumé}

Les notions de temps et d'espace au bout du millenaire se transforment sous l'avancement de la tecnologie de communication et d'information. Dans ce contexte, se répandrent les signes de la multiplicité, de la virtualité et de l'incertitude. Le but de cet étude est celui de présenter une lecture de Machado de Assis sous la perspective de l'experience contemporaine, surtout pour évaluer le discours du sujet-narrateur dans les contes O alienista et Missa do galo. En travaillant le concept de virtualité et les différences entre signification et sens, on cherche à démontrer comment, dans ces contes-là, la narration, en jouent avec l'ironie et l'ambigüité, casse la logique de l'interpretation et se jete dans le champs de l'indetermination du sens. 